\title{
Protein Furry Homolog-Like
}

National Cancer Institute

\section{Source}

National Cancer Institute. Protein Furry Homolog-Like. NCI Thesaurus. Code C126625.

Protein furry homolog-like (3013 aa, $\sim 340 \mathrm{kDa}$ ) is encoded by the human FRYL gene. This protein is involved in the regulation of cell shape in polarized cells. 